\title{
国土数值情報を用いた地上雨量観測所の 配置特性に関する研究 \\ A STUDY ON SPATIAL CHARACTERISTICS OF RAIN-GAUGE NETWORK OVER JAPAN USING DIGITAL NATIONAL LAND INFORMATION
}

\author{
林義晃 ${ }^{1}$ 手計太一 2 ・山㠃惟義 3 \\ Yoshiaki HAYASHI, Taichi TEBAKARI and Koreyoshi YAMASAKI \\ 1正会員 学士 福岡大学技術職員 工学部社会デザイン工学科（テ814-0180 福岡市城南区七隈8-19-1） \\ 2正会員 博 (工) 富山県立大学講師 工学部環境工学科（广939-0398 富山県射水市黒河5180) \\ 3 正会員 工博 福岡大学教授 工学部社会デザイン工学科（テ814-0180 福岡市城南区七隈8-19-1）
}

\begin{abstract}
To clarify the spatial characteristics of rain-gauge network over Japan, we studied some characteristics of rain-gauge network over Japan using available data observed by the Japan Meteorological Agency (JMA), the Water and Disaster Management Bureau under the Ministry of Land, Infrastructure, Transport and Tourism (WDMB-MLIT) and Local Government (L-Gov). Additional spatial analysis was also used available digital national land information (DEM, topographical slop, land use, surface geology, major road, natural park). As a result of spatial analysis using some digital national land information and observation blank zone, more than altitude $500 \mathrm{~m}$ area couldn't be installed rain-gauge stations. Some observation blank zones have been topographical slop were rich in ups and downs. Rain-gauge stations weren't installed in only limited land use or surface geology. Moreover, many rain-gauge stations tend to be installed near the major road. Therefore, some observation blank zones could install rain-gauge stations.
\end{abstract}

Key Words :Observation blank zone, altitude, topographical slop, land use, surface geology, rain-gauge network, flood management, water resource management.

\section{1. はじめに}

地上雨量観測は，降水量を定量的に把握することがで きる唯一の手法であり, 現業観測から治水計画などの 様々な計画や予測において重要な基礎データともなって いる. 我が国の地上雨量観測所は2010年度末時点で約 9600箇所以上あり, 高密度な雨量観測ネットワークが構 築されている ${ }^{1)}$ しかし，降水現象は時空間的に大きく 偏りがあり，その予測も極めて困難な自然現象であるこ とは自明である.さらに強雨や少雨といった極端な降水 現象は，治水や利水をはじめ社会経済活動一も大きく影 響を与える. よって, 雨量観測は気象庁や国土交通省を はじめ民間企業にまで幅広く実施されている.

降水量の観測には，地上雨量観測以外にレーダ観測が ある．近年では，XバンドMPレーダに代表されるよう に新しい観測技術が開発されており，これまでに捉える ことが困難であった狭小な雨域の詳細な降水特性も観測 できるようになってきた。 しかし，XバンドMPレーダ
の観測範囲は従来のCバンドレーダとくらべて狭く, 強 雨域の後背地では電波消散域となり久測しや寸く, 別の レーダとの合成や地上雨量観測データとの補間が必要と なる2). よって, 依然として地上雨量観測データの重要 性に変わりはない.

そのため，これまでに地上雨量観測所に関連する様々 な分野の研究が実施されている. 地上雨量観測所の雨量 データを用いた既往研究例は，暖候期降水量と各時間分 解能における極值降水量の統計的関係の解明 ${ }^{3)}$ ，台風の 影響を受けた地域において観測されたデータと各時間分 解能の降水量を比較することによる統計的評価 ${ }^{4}$ ，様々 な統計手法を用いて各地域における確率降水量を算出す る研究5),が挙げられる.

地上雨量観測所の空間分布に関する既往研究例として, 面積雨量や観測点密度に着目した雨量精度の算定に関す る検討 ${ }^{7}$, ダムや河川流域といった限られた地域におけ る観測所の最適配置と観測精度に関する研究8,9), 少数の 雨量データによる降水量分布モデルを用いた降水量推定 手法に関する研究10), メッシュデータを用いた雨量観測 


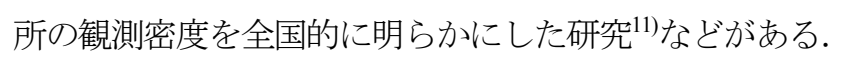
地上雨量観測所の地理的検討として，山岳地帯などの 高標高部に設置されていた観測所の観測手法の研究 ${ }^{12), 13)}$ などが行われている.

このように降水量データや観測所の配置，観測方法な ど地上雨量観測所に関する様々な研究が行われているが, 日本全国といった広域的視点における地上雨量観測所の 面的及び空間的解析を行った研究は少なく，様々な指標 を用いた地上雨量観測所の配置特性や新たな観測所の設 置条件を検討した研究は極めて少ない.

以上を鑑み，本研究では日本全国において雨量観測所 が展開されている気象庁と国土交通省水管理・国土保全 局 (旧河川局), 都道府県が管理する地上雨量観測ネット ワークを用いて，土地利用状況や表層地質などの国土数 值情報を用いた地上雨量観測所の配置特性を明らかにす る. 今回，研究対象地域として2004年と2011年に豪雨被 害を受けた新潟県と福島県, 2009年に豪雨被害を受けた 山口県, 国内屈指の多雨地域であり土砂災害が頻発しや すい熊本県, 宮崎県, 鹿児島県の3つの地域とした。 そ れらの地域において，地上雨量観測所の観測空白域にお ける観測所設置の可能性についても検証した.

\section{2. 使用するデータ}

既存の研究では，1つの観測機関が管理する雨量観測 ネットワークを用いることが多い.しかし，観測所の配 置特性はその観測目的に依存しやすいため，1つの観測 機関では全国の様々な降水現象を網羅できるとは言い難 い. そこで本研究では，日本全国に観測所を展開してい る気象庁 (以下，JMA）と国土交通省水管理・国土保全局 (同WDMB-MLIT), 都道府県 (同L-Gov)の3つの観測機 関が管理・運用する地上雨量観測所を研究対象とした.

\section{（1）解析対象とする雨量観測所}

JMAにおける雨量観測所の情報は，気象庁のホーム ページで公開されており，2008年1月1日時点の地域気象 観測所一覧に掲載されていた雨量観測所にて解析した. その総数は1361箇所であり，その空間配置の特徴は，全 国どの地域においても満遍なく分布している.

WDMB-MLITにおける雨量観測所の情報は，国土交通 省水管理・国土保全局のホームページ内にある水文水質 データベースにて公開されており，2008年9月1日時点で データが公開されていた雨量観測所にて解析した. その 総数は観測所の位置情報 (経度・緯度・設置標高) が明ら かになっている2172箇所とし，その空間配置の特徵は， JMAと比べると偏った分布になっている。 これは上記の 通り, 直轄河川の流域やダム周辺といった河川管理の観 点から必然に形成された配置である.

L-Govにおける雨量観測所の情報は，（財) 河川情報セ
ンターにて管理されている統一河川情報システムにおい て都道府県管理として登録されている観測所を解析対象 とした，その総数は4317箇所であり，非常に密に観測所 が設置されている都道府県がみられた，以上により，本 研究では3つの観測機関が管理・運営する地上雨量観測 所合計7850箇所を対象観測所として解析した.

\section{（2）解析に用いる国土数值情報について}

本研究では，様々な評価指標が観測所の設置に与える 影響を明らかにするため，ホームページ等で広く公開さ れている4種類の国土数值情報を用いて解析を行った.

地形データは, 国土地理院が発行する数值標高モデル (DEM)を用いた。地形条件と観測所設置標高の解析に

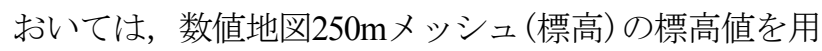

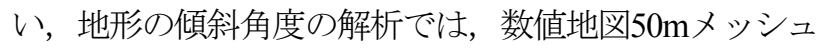
(標高)の標高值から角度を算出して解析を行った.

土地利用状況，道路と公園のデータは，国土交通省国 土政策局国土情報課のホームページ内で公開されている 国土数值情報ダウンロードサービスより「土地利用細分 メッシュ (平成18年度)」，「道路(平成7年度)」と「自 然公園地域(平成22年度)」を用いた。いずれのデータも 掲載されている分で最新版を用いており，土地利用状況

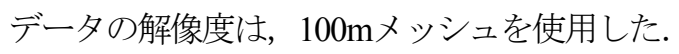

表層地質のデータは，国土交通省土地・水資源局国土 調査課のホームページ内で公開されている「20万分の1 土地分類基本調査」のデータを用い，そのうちの大分類 に相当する表層地質(属性1)のデータを使用した.

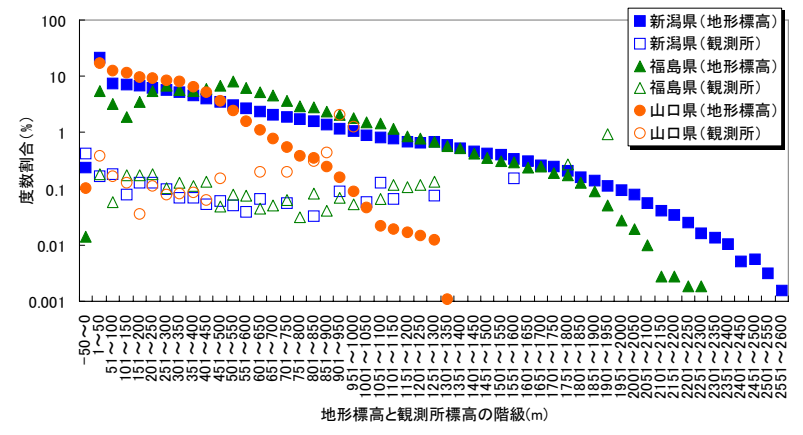

図-1 標高別の地形と観測所標高の度数割合 (新潟県, 福島県, 山口県).

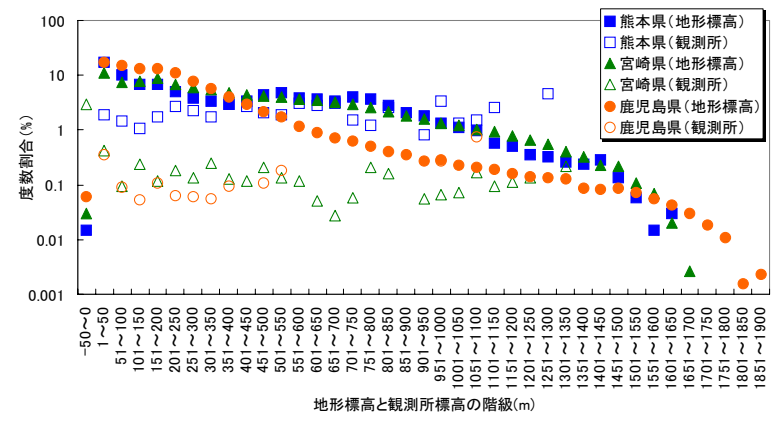

図-2 標高別の地形と観測所標高の度数割合 (熊本県, 宮崎県, 鹿児島県). 


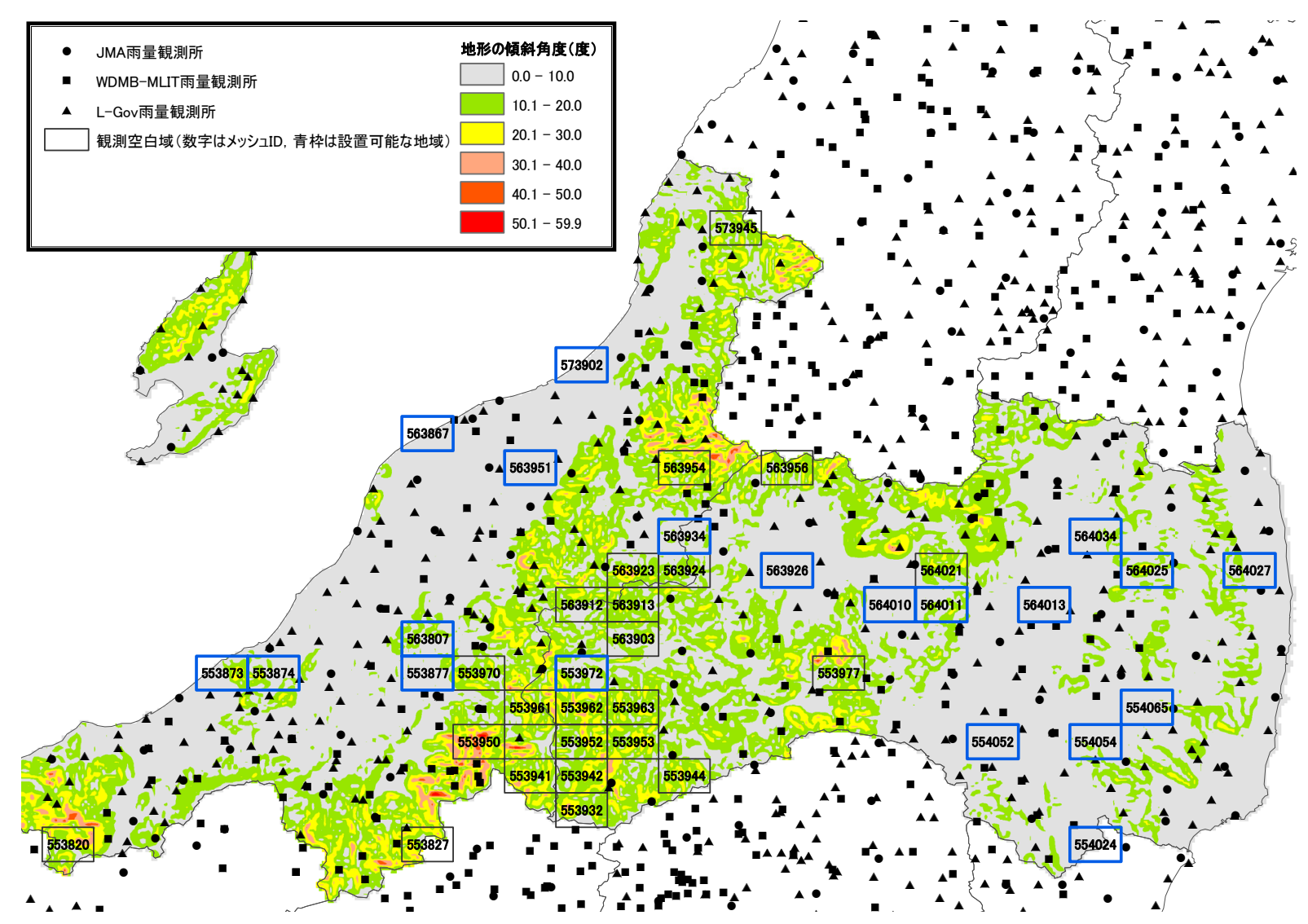

図-3 新潟県と福島県における観測空白域と傾斜角度の空間分布.

\section{3. 解析結果}

\section{（1）地形条件が観測所設置に与える影響}

図-1，2に研究対象である3つの地域の標高階級別の地 形度数割合と観測所標高の度数割合を対数表示で示す. ここで観測所標高の度数割合とは，各標高階級における 地上雨量観測所の設置数をその地形標高度数で除した割 合である.

これにより，各都道府県とも標高 $500 \mathrm{~m}$ 以上から観測 所が設置されていない標高階級が存在することがわかる。 特に, 高標高域においては観測所がほとんど設置されて いない．よって，平地では良好な観測体制であるが，高 標高域では地上雨量観測が不足しており，それによって 解析雨量の精度低下も示唆される. 次に, 標高階級に着 目した観測所のカバー領域率を検討した．観測所のカ バー領域率とは，各都道府県において観測所が設置され ている標高階級の数をその都道府県の地形標高データの 全標高階級の数で除した割合である。これにより，新潟 県が約 $42 \%$ ，福島県と山口県が約 $57 \%$ と各都道府県の全 標高階級のうち半分ほどは地上雨量観測所が設置されて いる. 熊本県と宮崎県では，約 $68 \%$ と約 $72 \%$ とや高い が，鹿児島県は約 $31 \%$ と極端に低いことがわかった.

\section{（2）地形の傾斜角度が観測所設置に与える影響}

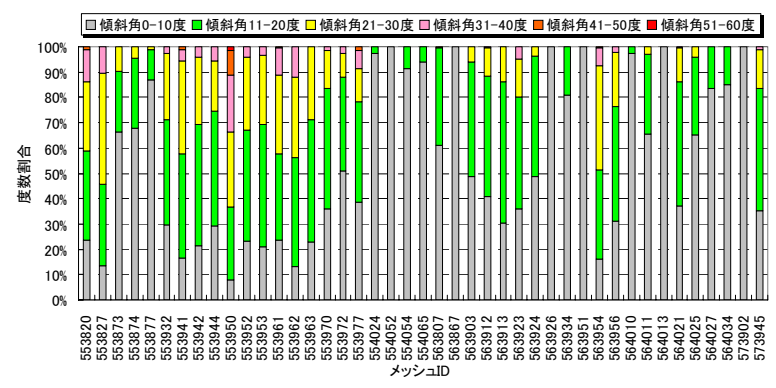

図-4 各観測空白域における傾斜角度の度数割合.

図-3に新潟県, 福島県における観測空白域と地形の傾 斜角度の空間分布を示す。ここで観測空白域とは，一辺 が約10kmのメッシュデータを用いた全国における地上


メッシュ内に地上雨量観測所が1箇所も設置されておら ず地上雨量観測ができない地域のことである.さらに, 海や湖沼等の地形データが十分得られない地域を除外す るため, 観測空白域においてメッシュ内の傾斜角度の データ数が $50 \%$ 未満の場合は解析から除外した.

それにより，観測空白域では図-3の中央部に多く見ら れるように非常に起伏に富んだ地形を有する地域が存在 し，観測所が容易に設置できないことが推測できる．同 時に，比較的平坦な地形を有する地域も存在することが わかった. 図-4に観測空白域内における傾斜角度の度数 割合を示寸。これにより，43箇所の観測空白域のうち約 4割強にあたる20箇所(図-3中の青色太枠のメッシュ)で 


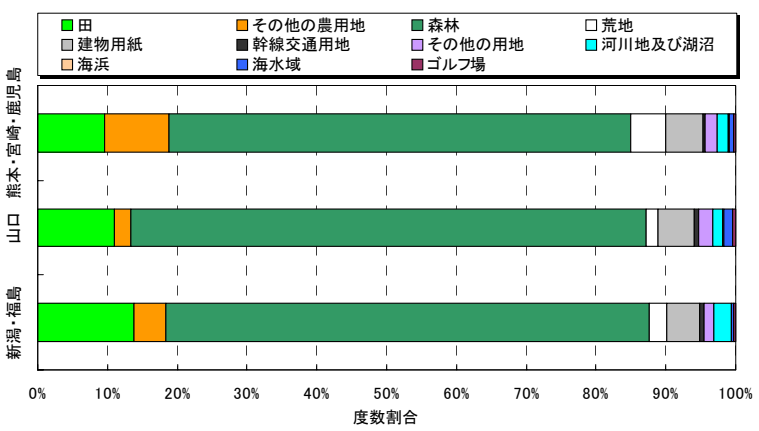

図-5 本研究対象地域における土地利用状況の度数割合.

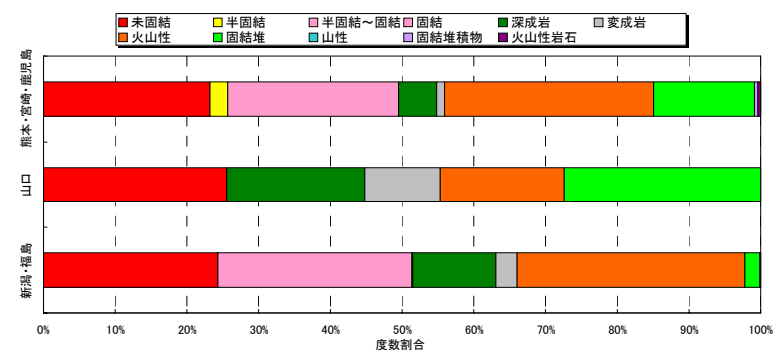

図-7 本研究対象地域における表層地質の度数割合.

傾斜角度が 10 度以下でその度数割合が $50 \%$ 以上あること が明らかになった。これは，良好な観測場と観測環境が 容易に確保できることが推察できる。 その他の地域とし て, 熊本県, 宮崎県, 鹿児島県でも, 新潟県, 福島県と 同様な傾向であった. よって, 地上雨量観測所の再配置 を検討する余地があることが示唆できる.

\section{（3）土地利用状況が観測所設置に与える影響}

図-5に本研究が対象としている3つの地域における土 地利用状況を示した度数割合を示す。これにより，どの 地域においても森林が全体の約7割を占めており，全国 と比較してもほぼ同割合14)であり，特異な土地利用状況 ではなく，各地域間でも大きな違いは見られない.

図-6に新潟県，福島県における観測機関別の地上雨量 観測所が設置されている箇所の土地利用の度数割合を示 す. 各観測機関とも森林と建物用地に多くの観測所が設 置されている，そして特筆すべき点は，全体の約 $5 \%$ し か占めていない建物用地において，どの機関とも約3割 の観測所数が設置されていることである。これは，他の 地域でも同様な傾向がみられた。よって，今後は各地域 における土地利用の変遷を明らかにし，地上雨量観測所 における周辺環境の変化についても検討する必要がある.

\section{（4）表層地質が観測所設置に与える影響}

図-7に本研究が対象としている3つの地域における表 層地質(属性1)の度数割合を示す。新潟県, 福島県と熊 本県，宮崎県，鹿児島県においては，全体の約7割が 砂・礫・泥といった「未固結や半固結」とシラスやロー ムといった「火山性」のいずれも風化物や破屑物で構成



図-6 観測所設置箇所の土地利用状況の度数割合 (新潟県, 福島県).



図-8＼cjkstart観測所設置箇所の表層地質の度数割合 (熊本県, 宮崎県, 鹿児島県)

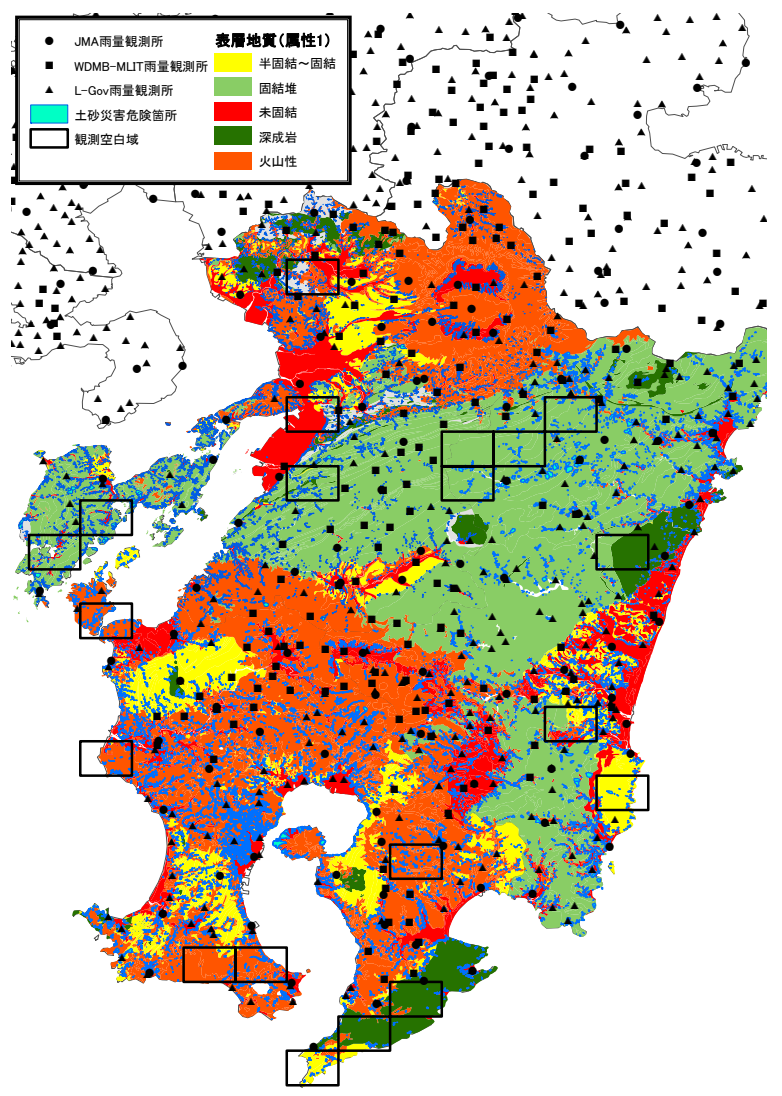

図-9＼cjkstart表層地質と土砂災害危険箇所の空間分布.

されており，一般的に脆弱になりがちな地盤であること がわかる。山口県については，「未固結と半固結」と 「火山性」がともに半分ずつの割合で構成されており, その原因の一つとして周辺地域における火山の有無とそ 


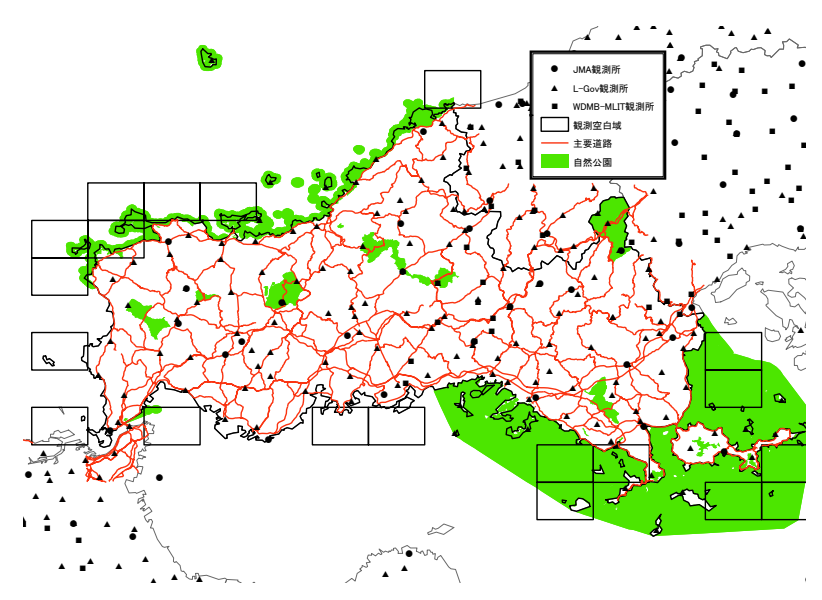

図-10 主要道路と自然公園に着目した地上雨量観測所の 空間分布 (山口県)

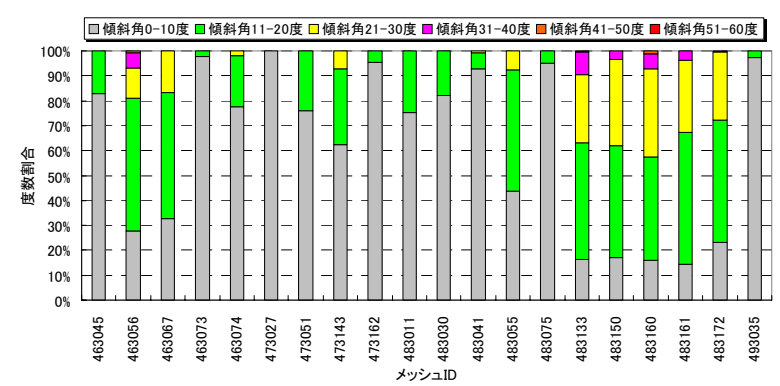

図-11 観測空白域内における傾斜角度の度数割合.

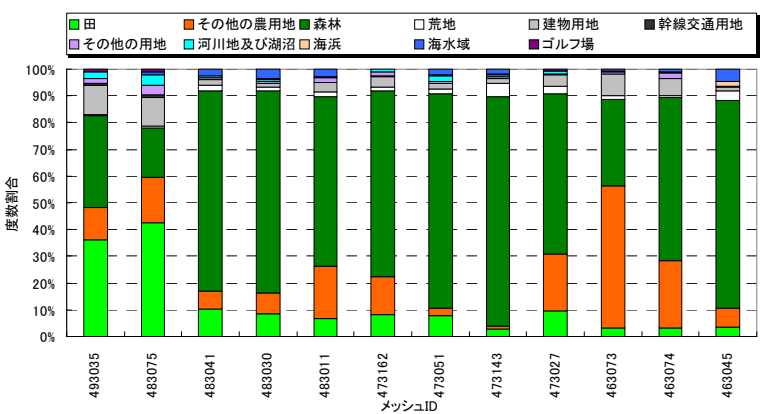

図-12 観測空白域内における土地利用状況の度数割合.

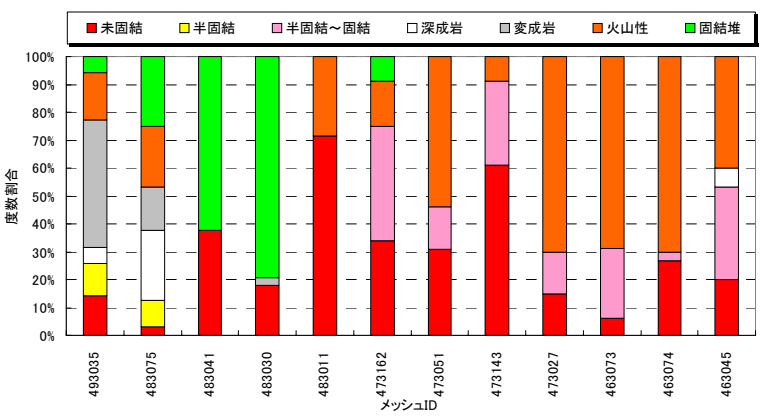

図-13＼cjkstart観測空白域内における表層地質の度数割合.

の活動の規模と履歴の影響が考えられる.

図-8は，熊本県，宮崎県，鹿児島県における観測機関 別の地上雨量観測所が設置されている箇所の表層地質の 度数割合を示す。これにより, 各観測機関とも属性によ らず観測所が設置されており，特定の地質区分に限って 配置されているわけではないことがわかった。これは,
他の対象地域でも同様な結果であった．さらに，未固結 や火山性といった脆弱になりがちな地盤上でも多くの観 測所が設置されていることから，観測所の設置において 地質区分の影響を強く受けないことがわかる。

図-9には熊本県, 宮崎県, 鹿児島県の表層地質と土砂 災害危険箇所の空間分布を示寸。ここで，土砂災害危険 箇所については，上記の国土数值情報ダウンロードサー ビス内で公開されている「土砂災害危険箇所」において 土石流危険区域，急傾斜地崩壊危険箇所及びその区域, 地すべり危険箇所及びその区域の3種類のデータを使用 した．これにより，土砂災害危険箇所は異なる地質の境 界部分に多く集中していることがわかった，さらに，ほ とんどの観測空白域内において土砂災害危険箇所が含ま れていることがわかった. 土砂災害を監視する上で最も 重要指標の一つは降水量であり, 地上雨量観測所の最適 な配置を検討する余地があることがいえる.

\section{（5）道路や公園が観測所設置に与える影響}

図-10に, 山口県における主要道路と自然公園に着目 した観測空白域の解析結果を示す，山口県における観測 空白域は全て沿岸域に存在し, 内陸部にはないことがわ かる. また，地上雨量観測所は主要道路の近傍に設置さ れていることがわかり，これは観測所運用に関する保 守・管理が要因の一つとして考えられる. 同時に, その ことが観測所の配置に影響することで，捉えることがで きない降水現象も生じることが推察される.

自然公園においては，特にJMAにおいて国立公園をは じめとする自然公園には地上雨量観測所が設置できない 要因の一つとなっている ${ }^{15)}$. しかし, 各観測機関とも園 内に地上雨量観測所を設置されており, 他の研究対象地 域においても同様のことが言えた．よって，その他の要 因も考えられるが，空間特性上必要であれば園内でも地 上雨量観測所は設置可能であることが示唆できる.

\section{（6）観測空白域における観測所設置の検討}

本節では, 熊本県, 宮崎県, 鹿児島県の観測空白域に おいて観測所設置の可能性を総合的に考察する. 解析対 象となる観測空白域は，全部で20箇所である(図-9参照)。

図-11に観測空白域における地形の傾斜角度の度数割 合を示す．設置可能な基準として，前節で使用した 「メッシュ内における地形の傾斜角度が10度以下でその 度数割合が $50 \%$ 以上」を用いた。 これにより，全体の約 6割にあたる12箇所で設置可能な地形条件であった。

次に，図-12,13にその12箇所における土地利用状況と 表層地質のデータを抽出して度数割合にしたグラフを示 す．それにより，土地利用状況においてはどの箇所も全 体の約7割が田とその他の農用地，森林であることから， 良好な観測場と観測環境が確保できると考えられる．表 層地質のデータより，メッシュID493035 と483075の2箇 所で6種類の地質が混在する分布になっているが，各地 


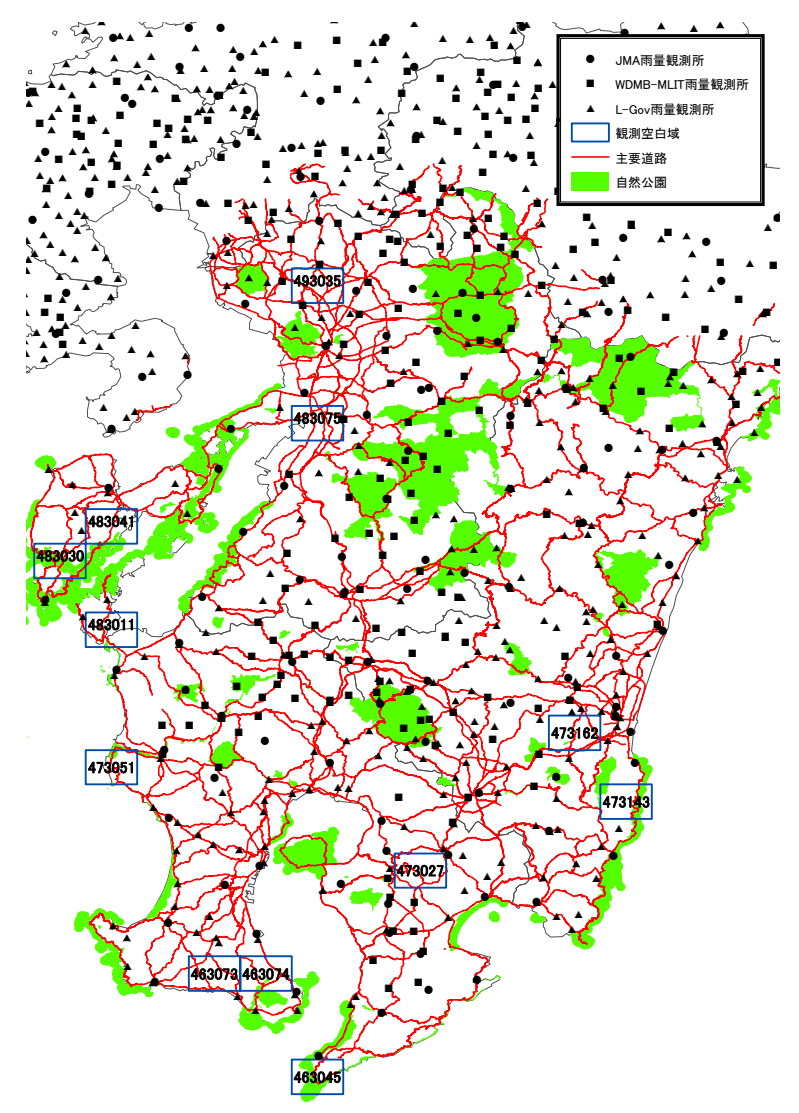

図-14 観測空白域における主要道路と自然公園の空間分布.

質区分の面積割合や土砂災害危険箇所，類似条件下で設 置されている既存の観測所等を考慮すると, 観測所の設 置は不可能ではないと考えられる. 図-14に主要道路と 自然公園に着目した観測所の空間分布を示寸. 全12箇所 とも主要道路が通じていることから保守・管理の点では 問題なく, また自然公園においても大きな影響はないこ とがわかる. よって, 図-14に示寸観測空白域には地上 雨量観測所が好条件で設置可能であると考える. なお， 前文で好条件と付言した理由は，本研究で検討した観測 所が設置可能と判断した独自基準(設置可能な地形の傾 斜角度とその度数割合など）の実用性や本検討以外の評 価指標についてもさらに検討寸る必要があるためである.

\section{4. 結論}

日本全国にわたる広域観測ネットワークを有する気象 庁と国土交通省水管理・国土保全局, 都道府県の地上雨 量観測所を対象に，土地利用状況や表層地質などの国土 数值情報を用いて地上雨量観測所の配置特性を検討した。

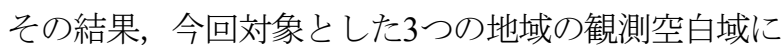
は, 地上雨量観測所が配置可能な箇所が多く存在するこ とが明らかになった．全国の約3割の地域において観測 空白域が存在すること ${ }^{11}$ から，その他の地域においても 同様な検討が必要である.さらに，その他の評価指標
(例えば植生の分布, 電力・通信の確保, 費用便益の経 済性等)についても地上雨量観測所の配置特性に与える 影響も明らかにし，様々な降水スケールに対応できる地 上雨量観測所の最適配置を提案する必要がある.

謝辞 : 本研究の遂行に際し, 気象庁と国土交通省水管 理・国土保全局(旧河川局)，（財)河川情報センター，各 都道府県より各種データを提供していただいた。 ここに 記して謝意を表します。

\section{参考文献}

1) 中尾忠彦 : 水文観測の現況と展望, 河川流量勧測の新時代 (水文・水資源学会研究グループ「河川流量観測高精度化研 究会」編)，Vol.1，pp.7-12，2010.

2) 真木雅之, 前坂剛, 加藤敦, Kim Dong-Soon, 岩波越 : Xバ ンドマルチパラメータレーダネットワーク合成雨量, 水 文・水資源学会2011年度研究発表会, pp.32-33，2011.

3) 牛山素行, 寶馨 : AMeDASデータによる暖候期降水量と最 大1時間・日降水量の関係，水文・水資源学会誌，Vol.16, pp.368-374, 2003.

4) 葛葉泰久: 九州中東部でのIDFカーブの作成と2005年台風14 号による豪雨の統計的評価, 自然災害科学, Vol.25, pp.525-540, 2007.

5) Shih S F: Rainfall Variation Analysis and Optimization of Gaging Systems., Water science and technology, Vol.18, pp.1269-1277, 1982.

6) 篠田昌弘: AMeDASデータを用いた確率降雨量マップ, 土 木学会論文集, Vol.63，pp195-205， 2007.

7) 川烟幸夫 : 水文気象学, 地人書館, pp.57-70, 1963.

8) 下垣久: ダム流域における雨量観測所の最適配置, 電力土 木, Vol.209, pp.99-110, 1987.

9) 福岡捷二, 谷岡康, 高本正彦: 都市中小河川流域における 雨量観測所の密度が面積雨量精度に与える影響, 水工学論 文集, Vol.37, pp.27-32, 1993.

10) SILVERMAN, B. A., ROGER, L. K. and DAHL, D.: On the sampling variance of raingage networks, Journal of Applied Meteorology, Vol.20, pp.1468-1478, 1981.

11) 林義晃, 手計太一, 山㠃惟義 : 複数の評価指標からみた地 上雨量観測所の観測密度に関寸る基礎的研究，水工学論文 集, Vol.55, pp.295-300, 2011.

12）五大均, 大津洋介, 小川達則, 植野利康, 長谷川賢市, 櫟 清彦: 山岳域の強風下における雨量観測に関する考察, 砂 防学会研究発表会概要集, Vol.2007, pp.370-371, 2007.

13）山田正, 藤田睦博, 茂木正, 中津川誠 : 山地流域における 降雨観測と降雨の特性について, 水工学論文集, Vol.34, pp.85-90, 1990.

14) 農林水産省林野庁: 森林 - 林業白書(平成23年版), pp.5556, 2011.

15) 気象庁: 地上気像観測指針(第2号)，149pp，2002.

(2011. 9. 30受付) 